DOI https://doi.org/10.30525/978-9934-588-92-1-12

\title{
ЛЕГІТИМНІСТЬ ТА НАЛЕЖНА ЮРИДИЧНА ПРОЦЕДУРА: АНАЛІЗ СПІВВІДНОШЕННЯ
}

\author{
Николина К. В. \\ кандидат юридичних наук, доцент, \\ дочент кафедри теорії та історії права та держави \\ Інституту права \\ Київського національного університету імені Тараса Шевченка \\ м. Київ, Украӥна
}

В сучасних умовах ускладнення суспільних відносин актуалізується необхідність теоретичної розробки процедурної форми, яка виступає гарантією легітимності юридично значимих дій. Значення процедурної форми складно переоцінити в сфері діяльності публічно-владних суб'єктів, оскільки вони зобов'язані діяти виключно в межах нормативно встановленого офіційного порядку. Це в свою чергу $є$ гарантією забезпечення прав людини, верховенства права, в тому числі дотримання принципу юридичної визначеності. Справедливо з цього приводу зазначає М. С. Смольянов, що головною причиною частих порушень прав людини виступає невисокий рівень практики і теорії процедурного регулювання[1, с. 3]. Будь-яка процедура вибудовує межі, в яких має діяти суб'єкт. В такому контексті вона виступає 3 одного боку засобом прогнозування його дій, а 3 іншого - обмежує прояви свавілля.

Основний сенс, ідея юридичної процедури i, отже, іï цінність, полягає в забезпеченні досягнення бажаного правового результату, який досягається шляхом подолання наслідків, викликаних людськими помилками і навмисними довільними діями. Простіше кажучи, юридична процедура виступає однією 3 основних гарантій забезпечення прав людини на всіх етапах від створення до реалізації права.

Однак, слід усвідомлювати, що офіційне закріплення певної процедурної моделі ще не є панацеєю від зловживань і свавілля з боку суб'єктів влади. Важливим моментом $\epsilon$ розробка чітких вимог i критеріїв юридичної процедури. Значна частина цих вимог розроблена в рамках доктрини «належної правової процедури» (due process), що сформувалася в країнах загального права - Великобританії і США. Вона функціонує в усіх розвинених країнах, i визначається як процесуальні принципи або процедурні гарантії. 
Для сучасної юридичної практики вже традиційними є цінності верховенства права, які серед іншого включають принципи передбачуваності (юридичної визначеності), процедурної справедливості. Процедурність як і нормативність є основними характеристиками права як соціального регулятора. На цьому наголошує і Генрі М. Харт, зазначаючи, що право власне і являє собою сукупність процесів соціального впорядкування, які встановлені з метою сприяння цілям, прийнятим як чинні (легальні) в суспільстві [2].

Питання належної правової процедури в сучасній українській юриспруденції досить фрагментарно досліджуються в межах галузевих наук i, як правило, пов'язуються з відповідним судовим процесом.

Відзначаючи суперечливість та неоднозначність поглядів стосовно розуміння належної правової процедури, вважаємо доцільним розглядати iii в широкому розумінні як юридичну процедуру, що відповідає комплексу чітко визначених вимог та принців, які $\epsilon$ обов'язковими для дотримання під час вчинення тих чи інших юридично значимих дій $[3$, с. 46]. Вимоги до належної юридичної процедури - це система універсальних базових ідей та принципів, які визначають характер і межі процедурного порядку реалізації правових приписів з метою забезпечення і захисту прав людини та дотримання загальнолюдських суспільних цінностей. На нашу думку, до них належать дотримання прав людини, законність, демократизм, узгодженість процедури 3 основними нормативними приписами, багатоваріантність (диспозитивність), передбачуваність, доступність та гарантованість.

Так само, як верховенство права історично вважалося центральним компонентом легітимної урядової системи, так само дотримання вимог належної юридичної процедури є основною підставою того, наскільки люди вважають владу та прийняті нею рішення легітимними.

Важливість концепції належного юридичного процесу або процедурної справедливості для публічної юридичної діяльності не викликає сумнівів. Разом з тим, останнім часом все більшого значення набувають процедурні принципи в межах неюрисдикційних видів юридичного процесу. Оцінка пересічними людьми легітимності юридичних процедур (як формальних, так і неформальних) безпосередньо залежить від дотримання процедурної справедливості, яка включає в себе такі характеристики як неупередженість, прозорість та повагу до прав людини [4].

Залежність легітимності від правильного застосування норм уповноваженими органами була проаналізована ще Максом Вебером в межах концепції раціонально-правової легітимності [5, с. 212]. 
В сучасних демократичних державах це має прояв на рівні закріплення процедурних стандартів здійснення юридичної діяльності, таких як неупередженість, прозорість, законність тощо.

Саме дотримання процедурних вимог та правил свідчить про легітимність досягнутих результатів або прийнятих рішень. Якщо влада потребує підтвердження, що та чи інша інституція має відповідні повноваження приймати рішення в певній сфері, то легітимність вимагає підтвердження, що ці повноваження здійснюються належним чином.

Отже, сам факт закріплення повноважень ще не гарантує досягнення бажаного результату. Необхідним $є$ ще правильне їх використання.

Варто наголосити, що роль процедурних правил залежить від типу правової системи. Зокрема, в англо-американській правовій системі цілком можливе винесення рішень без офіційних юридичних текстів, які встановлюють норми матеріального права. В такому випадку судді повинні керуватися не стільки законом, скільки тим, щоб на основі вільного судового розсуду діяти відповідно до права, яке підлягає захисту і до встановленої процедури судової діяльності.

В романо-германській правовій системі першочергове значення має вирішення юридичної справи на підставі конкретної правової норми, офіційно зафіксованої в законодавстві. Таким чином певні процедурні вимоги стають другорядними. Втім, наприклад, в Конституції України були внесені зміни і на сьогодні зазначається, що суддя у своїй діяльності керується верховенством права, а не законом як було в попередній редакції.

Отже, в судовій практиці виникають обставини, коли суддя змушений виносити рішення на підстави загальних принципів, стандартів захисту прав людини, актуальної судової практики. В такому разі легітимність прийнятих рішень може бути підтверджена лише дотриманням вимог належної юридичної процедури.

На нашу думку, схожа ситуація виникає і в межах неюрисцикційних процесів (альтернативних способів вирішення юридичних справ), оскільки держава в даному випадку використовує диспозитивний метод правового регулювання.

На сьогодні альтернативні способи вирішення спорів викликають певний скептицизм, оскільки юридична процедура в даному випадку чітко не врегульована офіційними нормами. Це може становити певну загрозу порушення прав однієї зі сторін спору, дає можливість прояву зловживань, а відповідно ставить під сумнів легітимність прийнятого рішення. Саме тому ми наголошуємо, що чіткі критерії в межах концепції належної юридичної процедури, які б поширювались на всі 
випадки прийняття юридично значимих рішень, повинні бути сформульовані на рівні правового регулювання.

\title{
Література:
}

1. Смольянов М. С. Юридическая процедура как гарантия прав человека: дисс. ... кандидата юридических наук. - Москва, 2011.- 198 с.

2. Henry M. Hart Jr. and Albert M. Sacks. Edited by William N. Eskridge, Jr. and Philip P. Frickey. New York: Foundation Press. 1994.

3. Николина К. Належна юридична процедура: теоретичні аспекти визначення. Вісник Київського національного університету імені Тараса Шевченка. Юридичні науки. 2012. Вип. 94. С. 44-46. Режим доступу: http://nbuv.gov.ua/UJRN/VKNU_Yur_2012_94_13.

4. Tyler, Tom R. and Hollander-Blumoff, Rebecca, «Procedural Justice and the Rule of Law: Fostering Legitimacy in Alternative Dispute Resolution» (2011). Faculty Scholarship Series. 4992. https://digitalcommons.law.yale.edu/fss_papers/4992

5. Weber, M. Economy and society. An outline of interpretive sociology. Edited By Guenther Roth and Claus Wittich. 3 Vols. New York: Bedminister Press, 1968. 1469 p.

DOI https://doi.org/10.30525/978-9934-588-92-1-13

\section{НАПРЯМИ ОПТИМІЗАЦІЇ ПРАВОВОЇ КОМУНІКАЦІЇ МГЖ ПРАВООХОРОННИМИ, ПРАВОЗАХИСНИМИ ТА СУДОВИМИ ОРГАНАМИ}

\author{
Погосян М. А. \\ адвокат, \\ аспірант кафедри історії і теорії держави та права \\ Запорізького національного університету \\ м. Запоріжжя, Україна
}

В умовах інформаційного суспільства правові відносини потребують модернізації форм взаємодії, однією 3 яких виступає правова комунікація. Сьогодні комунікативна взаємодія становить основу ефективних правових відносин між органами публічної влади та інститутами громадянського суспільства. 3 метою забезпечення динамічного розвитку правової системи України, грунтовного 